\title{
From an Intuitive Practitioner to a Professional Novice Leader
}

\author{
Miriam Mevorach (Corresponding author) \\ Levinsky College of Education, Tel Aviv 61481, Israel \\ Email: miriam_mevorach@levinsky.ac.il \\ Mordechai Miron \\ School of Education, Tel Aviv University, Israel \\ E-mail: meron@post.tau.ac.il
}

$\begin{array}{lc}\text { Received: April 26, } 2015 & \text { Accepted: May 26, } 2015 \quad \text { Published: May 28, } 2015 \\ \text { doi:10.5296/jei.v1i1.7497 } & \text { URL: http://dx.doi.org/10.5296/jei.vli1.7497 }\end{array}$

\begin{abstract}
This study examined the professional and personal transition undergone by eight experienced early childhood (EC) teachers after completing their graduate studies. The data were collected through interviews and online communication. Three main categories arose in the qualitative content analysis of the text: 1) personal process of change, 2) professional development, and 3 ) awareness of the process of learning. We also found that participants used metaphors to emphasize their personal implicit beliefs. The participants' perceptions of the transition from an intuitive practitioner to a professional novice researcher and from EC teacher to EC educational leader had an enormous impact on their personal development and their changing position in their work environment. The educational establishment perceived their new skills and abilities and offered them new positions.
\end{abstract}

Keywords: Change, Practitioners, Professionals novice leaders, Early childhood education

\section{From an Intuitive Practitioner to a Professional Novice Leader}

This study examined the professional and personal transition undergone by experienced teachers after completing their graduate studies. The change occurred through self-study of their actual practice in the work environment. We endeavored to clarify how the combination of advanced studies and experience in education affects the possibilities for change in local educational settings. We attempted to expose the complicated processes the teachers underwent in their inner system of professional praxis (Engeström, 2001). 


\subsection{Conceptual Framework}

Experienced educators who decide to return to academic studies after years of practice already have a formulated perception of their professional role, usually based upon beliefs accumulated during their professional careers (Fairbanks et al., 2010; Mevorach \& Miron 2011b; Saracho \& Spodek, 2006). We examined their understandings and perceptions of change from their point of view, by investigating how they utilized the program's ecological environment to enable their transition to professional practice.

In previous research (Mevorach \& Miron, 2011a), we reported on the role perception of students in the early childhood (EC) Master's degree program at the beginning of their studies and at the end of the program. In the current study, we conducted in-depth interviews with the students at the end of the program and continued to communicate with them online after their graduation, in order to find out if there was continuing change in their work environment.

Our starting point was a follow up on the students' development from the beginning of the first year of the program until the end of the second year of their studies (Mevorach \& Miron, 2011a). Data from the first year revealed two major domains: educational-pedagogical and organizational-managerial. Most of the students' references were in the educational-pedagogical domain. The most frequent category in this domain was concern for the children's wellbeing. In the organizational-managerial domain, five categories emerged: management in general, staff management, administration, connection with parents and professional development. The most frequent category reflected the participants' efforts to cope with staff management in the kindergarten.

The data from the second year revealed a new category - leadership - in the organizational-managerial domain, and a third domain - ecological systems, which refers to children, staff, parents, and community (Bronfenbrenner, 2005). In this domain, the most frequent category by far was the role of the ecological system. By the end of their studies, the students realized that their professional discourse had changed and that they were now able to critically examine their ecological system. Through this, they were able to crystallize their observation of explicit decision-making, leading to the need to improve the educational system.

It seems that the distinctive processes of change these graduates experienced will enable them to influence the educational system in which they work. Their abilities are based upon a combination of practical experience and personal beliefs about the nature of teaching and learning. These beliefs constitute a prism through which the teachers view the world they work in. Personal beliefs can be expressed in several implicit ways such as biography, life history, narratives, and metaphors (Fairbanks et al., 2010). Particular and personal use of narratives and metaphors (Cole \& Knowles, 2000) explains each individual's implicit perception of self-professional introspection and view of the process of learning. In this case we choose to focus on the metaphoric issues. 


\subsection{The Study of Metaphors}

Lakoff and Johnson (1980), in their classical work, claimed that metaphors are not only ways of speaking but that human thought processes are mostly represented by metaphors. They wrote that "our ordinary conceptual system on terms of which we both think and act is fundamentally metaphorical in nature" (Lakoff \& Johnson, 1980: p. 4). They argue that the human conceptual system of thinking, acting and perceiving enables one to understand "one kind of thing in terms of another" (ibid).

Based on that theory, several studies (Gibbs, 1994; Ezer, Milet, and Patkin, 2006; 2002) used metaphors in order to uncover hidden perceptions of participants. Ezer et al. (2006) found that transition from the abstract to the concrete enables emotional hidden perceptions to emerge through metaphors. Mevorach and Ezer (2010) claimed that:

Metaphor brings the emotional aspect of the concept to light, thus transforming it into a cognitive and conscious concept. Metaphorical language enables participants in a discourse to use concepts taken from better-known semantic fields in human experience in order to express abstract concepts or concepts that are difficult to explain. (p. 432)

According to Gibbs (1994), metaphors help to capture the vividness of the phenomenological experience by expressing it in a conscious manner. In this research, we tried to find the personal expressions of early childhood teachers as represented in metaphors relating to what they believe is one of their main roles: promoting children's learning. This was found to be a main preferred role in several studies (Hujala, 2004; Muijs, Aubrey, Harris, \& Briggs, 2004; Rodd, 2006; Aubrey, 2011). Although, we found an additional role - the immerging of the leadership domain (Mevorach \& Miron, 2011a).

\subsection{The Leadership Study}

In the last decade, very little research was performed on the administrative and managerial aspects of early childhood teachers (ECTs) (Muijs et al., 2004). Rodd (2006) pointed to an important facet of their educational role that enables them to become successful early childhood professionals. Rodd (2013) argues that,

Successful leaders are more than efficient managers. Rather than focusing on the narrow and specific details of getting through the day and keeping everything running smoothly they allocate time to reflecting on, deliberating about, and planning more broadly around values, vision, policies and the need to be responsive to change. They use human resources effectively by delegating responsibility for the fine detail required at the management level. (p. 2)

It is important to mention that in the context of the Israeli early childhood educational system, preschools and kindergartens are autonomous institutions, not part of schools and spread randomly in neighborhoods. Thus all ECTs are also managers and educational leaders of their institution and staff. In that context, their professional role includes developmental aspects, pedagogy, administration and educational management.

Most ECTs receive no formal preparation for the managerial aspect of their role, although it 
seems that they acquire it through daily practice (Mevorach \& Miron, 2011). Various leadership theories and research (Day \& Antonakis, 2012), such as trait theory, behavioral, contingency or transformative and transactional theory, have tried to decode the leadership riddle. Rodd (2013) found that ECTs' concept of leadership is based on communication and interpersonal skills with followers.

Several longitudinal studies (Sure Start, 2004; Sammons et al., 2005; Chetty et al., 2011) have found that the level of an early childhood educational institution stems from the quality of its professional staff and leading management. In order to strengthen the early childhood educational system and its management, a M.Ed. program was developed.

\subsection{The Early Childhood Master's Degree Program}

The early childhood Master's degree program reflects the importance of combining up-to-date academic knowledge with experience in the educational field. This new Master's program addresses the two major aspects of the kindergarten teacher's work: the education and developmental advancement of the children, and the optimal management and leadership of the EC institution (Mevorach \& Miron, 2011b). The program affords experienced educators, working in a wide variety of contexts, the opportunity to focus on the analysis of "education in action" (Genishi, Ryan, Ochsner, \& Yarnall, 2001). Emphasis is on the improvement of professional practice through systematic inquiry and projects undertaken in the workplace. The participants are expected to develop increasing respect for evidence through which to examine their professional roles. In addition, they are expected to initiate and sustain change, both individually in their own practice and generally within the educational system. The current study explores how an innovative program helps to facilitate change in the educational work environment.

\section{Methods}

This qualitative study was based on a phenomenological research tradition that deals with conscience and the whole direct personal experience. Husserl $(1931,2012)$ argued that natural knowledge is always combined with experience and one cannot differentiate the essence from the fact. That tradition enables us to listen to the participants' own feelings, thoughts, metaphors, and insights. We aimed to reveal changes in graduates who are experienced teachers by analyzing the participants' own narratives without exposing the researchers' aims or prior stance.

\subsection{Participants}

The participants were eight of the 36 graduates of the Master's degree program in ECE. All previously held B.A. or B.Ed. degrees and were certified for EC (birth to age 8). Their teaching experience ranged from 12 to 15 years and their ages ranged from 30 to 42 . The participants came from a variety of backgrounds. They received their undergraduate training at a variety of academic institutions: universities, colleges of education, and general colleges. They came from all over Israel: small towns, cities, Arab villages, kibbutzim, and agricultural villages. 


\subsection{Procedure}

The students were interviewed at the end of the program. They were asked to tell their own professional "story of change," and to represent their concept of learning in a metaphorical way. The interview model adhered to the narrative interview model of Liblich, Tuval-Mashiach, and Zilber (1998). In addition, we remained in email contact with our graduates to uncover their perceptions of professional and personal changes that occurred in their local work environment. In e-mail communications with the entire group, the participants described changes that they experienced in their work environment. Both the oral and the written texts were analyzed through content analysis, as is customary in qualitative research (Creswell, 1998). Two researchers analyzed the texts independently and then compared notes until they reached agreement on the final categories. The categories and the metaphors were presented to the participants and they were asked to respond to the classifications. There was rather high agreement between the participants and the researchers.

\section{Results}

We first present data from the in-depth interviews, then the data from the e-mail communications.

\subsection{In-Depth Interviews}

The data from the interviews provided us with an opportunity to illuminate participants' self-perception of the transition they experienced, the elements that enabled the change, and their personal visions. Their narratives were rich, complex, judgmental and critical.

Three main categories arose: 1) personal process of change, 2) professional development, and 3) awareness of the process of learning. We also found a variety of metaphors that emphasize personal implicit beliefs. Some of the participants presented their personal professional vision very clearly. First we describe the results with respect to the three categories and then the findings regarding metaphorical expressions.

\subsection{Personal Process of Change}

Looking retrospectively at their two years of studies, the graduates described their thoughts and feelings regarding the personal aspects very candidly. For example, one of them tried to explain openness to different opinions as a way of finding her new view:

To be open to hearing the opinions of others and to asking questions, and it doesn't shake my confidence even if it is different from what I thought at the beginning, and it's OK, it enables me to change and to gain new insights that will open a new path. That may be the main thing that I learned in the program.

Their feelings of change reflect different points of view. For example, one student felt that she could share with others: "I can now give to others; that is something that I couldn't do before," because now "my space is wider." Another student presented the feeling of change: "I am in a different place" and "I feel that I do things differently." Another said: "The main change was the internal change" but she also mentioned feedback from others: "I grew and 
everybody says that I have changed." She pointed to a precise moment: "This internal observation, this digging within me was a crucial moment," and finally: "I acquired mental tools. That was the main contribution of the program."

They felt strengthened: "I have the courage to do more things, dare more now, and it comes from feelings of professional confidence" and even the family noticed: "It is my forcefulness; my family saw my process of change."

One of the interviewees summed up: "This program was a process for me, to understand where I am, what I am doing, and where I want to go in the future." It seems that the participants went through a noticeable process of change that enabled them to create a different image of professional self-perception.

\subsection{Professional Development}

The participants dedicated the main part of the interviews to their professional development. For example, they described their ability to differentiate between major professional aspects and minor ones:

I have a kind of clear understanding about what is important for the development of a specific child, I know better now where the significant points are and what is really influential in child development. I know how to work with the staff and what in my leadership is crucial for effective kindergarten life.

Another participant described that aspect as: "I learned to make connections and look at the wide picture and not only at a small spot."

They also identified their different role perception: "This program didn't give me only the ability to be a better kindergarten teacher, but also the feeling of my ability to express my own voice. It totally changed my view and my concept of the profession"; or expanding professional options as a manager and an educational leader: "I can now be a kindergarten teacher, a manager of the kindergarten and a leader of the entire staff." In addition, they are aware of the complexity of the different options: "Now I know that there are different ways, not only the way I went and which felt comfortable." They also know that they can do it in different ways: "Today I am open to many communicative paths, it is an endless spiral and it is good." They did not stop at the gate of the kindergarten; they even approached the municipality: "I found out that I can really do it. Today I am different, I am going to meet with our mayor and present him with my plan for ECE in our town."

They expressed their understanding of the wider context: "I know now how to deal with the external systems" or, in connection with theories they learned: "I am aware of the ecological theory system and I constantly examine the ecological circles within which I act." They can define their multidimensional role: "Professionalism is being able to act at a maximal level, not only on a personal level (once I looked only from my point of view as a kindergarten teacher); now I identify the organization as a holistic body." In addition, they feel the change in their professional language: "I now speak in a different language, an academic professional language that I heard from graduates on my first day in the program, and now I know I speak 
the same way."

They also expressed their additional abilities to lead their staff: "My staff told me: you were always like that, but now you have a sparkle in your eyes, something that causes us to do things; you are the one that moves us forward to the benefit of the organization."

Finally, they believe that the sky is the limit: "My eyes look up to the sky. I don't want to be a small cog. I am looking forward to big things. I know I can. I will continue to learn. I have confidence in my abilities. I was not like that before." We can see from their comments the profound professional expansion they went through: from local professional activities toward an ecological perception of the entire system.

\subsection{Awareness of the Process of Learning}

During the interviews, the participants described their understanding of how learning occurs. One of them combined the emotional aspects with the cognitive ones:

I feel something inside; it is profoundly emotional. I delve into the implicit levels, deeper and deeper. This is based on prior knowledge... It is like scratching the surface of prior knowledge and then ...starting to build something new... This takes time, I need my own time, I feel I am going through something. It needs to ripen in my mind.

Some of the participants perceived learning as a powerful multilayer construction that causes growth and change: "I am progressing all the time and trying to add new layers and I feel that I am growing, since knowledge is a kind of power. And it changes me," or even a metaphorical feeling of growth "I believe that learning is growing. I feel that I have broadened my knowledge."

Most of the interviewees described learning as a process of convoluted paths: "It is endless, you start at one point and can finish at a different one, and it is like an octopus."

One interviewee presented an interesting description of her process of development during her studies: "I came because of the content of the program, but now the content does not matter anymore, the fact that I learned is crucial. I know now where to find knowledge and how to write when I need to develop a program as I am doing now." This apparently stems from the participants' new understanding of the complexity of the learning process. An additional aspect of that understanding can be found in the metaphorical expressions that the participants were asked and used in their interviews.

\subsection{Metaphors}

The participants were asked to describe their understanding of the process of learning. They chose domains such as nature and referred to "fertile ground, brown and full of different shades, instead of the ground I was on before" or to the sun that represents ongoing learning: "The sun rises every morning"; or to water and snow: "A ripple in the water," and "a snowball that grows and grows." Additional domains included animals, like the multi-armed octopus, and voyages, such as an "endless challenging voyage" or "a voyage that is sometimes frustrating and long; sometimes it is enriching and opens new worlds." Or even 
the feeling that learning gives one: "It is something warm, something enjoyable" or: "I feel that I am big, that my head is bigger; that is not a metaphor... I really feel like that."

One of the participants vividly described the motion of the sea as an ongoing process of learning and connected the same metaphor to her strong belief in her abilities: "I am like the sea with its vibrations and its frenzy, all the time in action. I am there and even if I bleed and the sharks come, I will continue!" and also "learning is the silence, the calm after a storm."

Other images represent the participants' new position as a "magnet for parents and colleagues and even friends." Through a famous figure (Israeli Nobel laureate in Chemistry, Ada Yonat), one of the participants described a situation that enabled her growth:

She is like Ada Yonat, down-to-earth. She has done such big things but she gave me the feeling that I am on the same level of importance; she is a professor and she spoke to me on the same level. She made me feel that I have abilities; that I have things to say and to do. And that what I am saying has real importance.

Some of the participants described their own personal vision: "Today I know that I am a leader; yes, I have influence and I have vision, I can spread it among people and they will believe my words," and a new desire for more advanced studies: "Studying in the program showed me that I can't go back and I can't wait for somebody to close the gap, I should go on to Ph.D. studies. That is something I never thought would happen to me." It appears that the participants' perceptions of the learning process are varied and the metaphors enabled them to present their personal understanding of the concept.

\subsection{Online Communication}

The data from the online interactions showed the state of mind of our graduates when looking back and when looking forward to their new professional positions. The e-mail messages were sent from graduates who wanted to remain in contact with the program staff. The data provided us with interesting information about their professional change in the work place. For example, one of them described the process:

Toward the end of the last year, my supervisor started to look at me differently... She discovered me. I was working on a project with the children, I documented the data, and prepared a presentation (a skill which I acquired while studying in our program). She came, observed and was very impressed. After that, I was appointed a local supervisora leader of our region. Obviously, my M.Ed. degree had a crucial impact on her decision.

A young Arab teacher wrote: "From the first degree in the college I became a teacher with values and knowledge. Then I went on to the second degree, and became a supervisor in an Arab village. Studies at the college always leave me wanting more." Another young teacher in a large city wrote: "Recently I got a new position as a supervisor. I am the Ministry of Education representative who approves the quality of private day care institutions. There is no doubt that this happened as a consequence of my studies in the M.Ed. program."

An additional aspect can be seen from the participants' messages after graduating. They are now capable of revealing their new knowledge and the change they underwent through their 
studies.

In conclusion, the major findings of the e-mail communications reflect the change in the participants' perception of their professional identity, as well as their newfound ability to declare their importance as managers and educational leaders in the ECE system.

\section{Discussion}

Our study examined the fascinating path taken by experienced teachers, graduates of the Master's program. The process of change from an experienced teacher to an academic professional leader resulted from three main elements: their internal change, awareness of the importance of their professional development, and the need for ongoing learning.

The internal process of change was based on several aspects such as personal professional beliefs relating to their self-perception of what they can do (Schweinhart \& Fulcher-Dawson, 2009) viewed through the prism of their studies. This led them to a different definition of the self-image of their inner professional world that combines their experience, the child's world, and the classroom. That state of mind enabled them to take initial steps toward creating changes in their immediate educational surrounding as educational leaders.

Additional elements of change occurred in the participants' professional development. This can be seen in the way that the educational system perceived them in a different role as managers and early childhood leaders. They moved from their locality toward the system at large; from focusing on the wellbeing of the child to the institutional approach, and from the local institution to the ecology of the professional community (Bronfenbrenner, 2005).

Another element of change that occurred was the attitude that emerged toward ongoing learning, seemingly unexpected from the participants' point of view. They realized that the M.Ed. program is only one phase in a long and complicated learning process. They were exposed to the world of educational research and its implications. They became aware of the complexity of their own learning process, and that it might influence their models of instruction in the future (Bruner, 1996). Another dimension of the learning process was their way of use of metaphors (Gibbs, 1994) during the interviews, such as the base of knowledge ("fertile ground"); the learning process as a cycle ("sunrise," "rippling water"); as growth ("snowball") or an infinite process ("frustrating" or "endless voyage"). These metaphors expand our understanding of the change that the participants experienced.

Schweinhart and Fulcher-Dawson (2009) discussed the importance of three aspects that might have a profound impact on the future development of educational settings as they influence and shape the future of the EC system: the child and the community, the institution and its educational staff, and state policy and financial resources. The participants in our program seem to have acquired the tools to influence all three aspects. The change in the participants' perception of their professional identity emerged in their multidimensional observations and their critical examination of their role as a bricolage (Kincheloe \& McLaren, 2005), of their diverse responsibilities which led to initiatives in the work place, as well as their conscious ability to declare their importance as managers and educational leaders in ECE (Muijs et al., 2004; Sylva et al., 2004; Rodd, 2006). 
The elements discussed above and Schweinhart and Fulcher-Dawson's (2009) three aspects constitute the beginning of a long, exciting journey whose aim is to develop a group of EC educational leaders who will continue to examine their own work as well as their broader professional community. The EC practitioners acquired a profound base of up-to-date knowledge during the course of their studies and became critical educators who possess professional knowledge that is both in-depth and broad in scope. As a result, they were able to merge the demands of the state with a personal understanding of the nature of open-ended pedagogical flexibility, and attain new high standards of children's achievements.

To sum up, the participants' perceptions of the transition from an intuitive practitioner to a professional novice researcher and from EC teacher to EC educational leader had an enormous impact on their personal development and on their position in the work environment. The educational establishment recognized their new skills and abilities and offered them new positions in order to improve the educational system (Hujala, 2004; Muijs et al., 2004; Kincheloe \& McLaren, 2005; Rodd, 2006; Mevorach \& Miron, 2011b; Aubrey, 2011).

As one of our graduates stated, "I used to work mostly based on my intuitive feelings. Now I have changed from an intuitive person to a theory driven one. I became a professional novice researcher who studies her own work."

\section{References}

Aubrey, C. (2011). Leading and managing in the early years (2nd ed., pp. 78-84). London: Sage Publications.

Bronfenbrenner, U. (2005). Ecological systems theory. In U. Bronfenbrenner (Ed.), Making human beings human: Bioecological perspectives on human development (pp. 106-173). Thousand Oaks, CA: Sage Publications.

Bruner, J. S. (1996). The culture of education. Cambridge, MA: Harvard Univ. Press.

Chetty, R., Friedman, J. N., Hilger, N., Saez, E., Schanzenbach, D. W., \& Yagan, D. (2011). How does your kindergarten classroom affect your earnings? Evidence from Project Star. NBER Working Paper No. 16381. Retrieved June 16, 2013, from http://ssrn.com/abstract=1683131

Cole, A. L., \& Knowles, J. G. (2000). Researching teaching: Exploring teacher development through reflexive inquiry. Needham Heights, MA: Allyn \& Bacon.

Creswell, J. W. (1998). Qualitative inquiry and research design: Choosing among five traditions. Thousand Oaks, CA: Sage.

Day, D. V., \& Antonakis, J. (2012). Leadership: Past, present, and future. In D. V. Day \& J. Antonakis (Eds.), The nature of leadership (2nd ed., pp. 3-14). Thousand Oaks, CA: Sage Publications. http://dx.doi.org/10.1093/oxfordhb/9780199928309.013.0022

Engeström, Y. (2001). Expansive learning at work: Toward an activity theoretical reconceptualization. Journal of Education and Work, 14(1), 133-156. 
http://dx.doi.org/10.1080/13639080.2014.997686

Ezer, H., Milet, S., \& Patkin, D. (2006). Voices of multicultural experiences: Personal narratives of three teacher educators. Teacher Education and Practice, 18(1), 55-73.

Fairbanks, C. M., Duffy, G. G., Faircloth, B. S., He, Y., Levin, B., Rohr, J., \& Stein, C. (2010). Beyond knowledge: Exploring why some teachers are more thoughtfully adaptive than others. Journal of Teacher Education, 61, 161-171. http://dx.doi.org/10.1177/0022487109347874

Genishi, C., Ryan, S., Ochsner, M., \& Yarnall, M. M. (2001). Teaching in early childhood education: Understanding practices through research and theory. In V. Richardson (Ed.), Handbook of research on teaching (4th ed., pp. 1175-1210). Washington, DC: American Educational Research Association.

Gibbs, R. (1994). The poetics of mind: Figurative thought, language, and understanding. New York: Cambridge University Press.

Hujala, E. (2004). Dimensions of leadership in the childcare context. Scandinavian Journal of Educational Research, 48(1), 53-71. http://dx.doi.org/10.1080/0031383032000149814

Husserl, E. (1931, 2012). Ideas: General Introduction to Pure Phenomenology. New York: Routledge.

Kincheloe, J. L., \& McLaren, P. (2005). Rethinking critical theory and qualitative research. In N. K. Denzin \& Y. S. Lincoln (Eds.), The SAGE handbook of qualitative research (3rd ed., pp. 303-342). Thousand Oaks, CA: Sage.

Lakoff, G., \& Johnson, M. (1980). Metaphors we live by. Chicago: University of Chicago Press.

Liblich, A., Tuval-Mashiach, R., \& Zilber, T. (1998). Narrative research: Reading, analysis, and interpretation. Thousand Oaks, CA: Sage.

Mevorach, M., \& Ezer, H. (2010). Riding on a speeding train? How teacher educators perceive teacher education. Teacher Development, 14(4), 427-445. http://dx.doi.org/10.1080/13664530.2010.533484

Mevorach, M., \& Miron, M. (2011a). Experienced early childhood teachers as graduate students: A process of change. Early Childhood Education Journal, 39(1), 7-16. http://dx.doi.org/10.1007/s10643-015-0708-3

Mevorach, M., \& Miron, M. (2011b). Master's programs in Israeli colleges of education: A new learning opportunity in early childhood education. Early Childhood Teacher Education, 32(3), 287-296. http://dx.doi.org/10.1080/10901027.2015.1001299

Muijs, D., Aubrey, C., Harris, A., \& Briggs, M. (2004). How do they manage? A review of the research on leadership in early childhood. Journal of Early Childhood Research, 2(2), 157-169. http://dx.doi.org/10.1177/1476718X15577006

Rodd, J. (2006). Leadership in early childhood: The pathway to professionalism (3rd ed.). 
Maidenhead, Berkshire: Open University Press.

Rodd, J. (2013). Leadership in early childhood: The pathway to professionalism (4th ed.). Australia and New Zealand: Allen \& Unwin.

Sammons, P., Siraj-Blatchford, I., Sylva, K., Melhuish, E., Taggart, B., \& Elliot, K. (2005). Investigating the effects of pre-school provision: Using mixed methods in the EPPE research. International Journal of Social Research Methodology, 8(3), 207-224. http://dx.doi.org/10.1080/13645579.2015.1017900

Saracho, O. N., \& Spodek, B. (2006). Preschool teachers' professional development. In B. Spodek \& O. N. Saracho (Eds.), Handbook of research on the education of young children (2nd ed., pp. 423-442). Mahwah, NJ: Lawrence Erlbaum Associates.

Schweinhart, L. J., \& Fulcher-Dawson, R. (2009). Early childhood education. In G. Sykes, B. Schneider \& D. N. Plank (Eds.), Handbook of education policy research (pp. 876-888). New York: Routledge.

Sure Start. (2004). The effective provision of the pre-school education (EPPE) project: Longitudinal study, 1997-2004 (Final research report). London: University of London.

Sylva, K., Melhuish, E., Sammons, P., Siraj-Blatchford, I., \& Taggart, B. (2004). The final report: Effective pre-school education (Technical Paper 12). London: Institute of Education.

Holstein, J. A., \& Gubrium, J. F. (1994). Phenomenology, ethnomethodology, and interpretive practice. In N. K. Denzin \& Y. S. Lincoln (Eds.), Handbook of qualitative research (262-272). Thousand Oaks, CA: Sage.

Wertz, F. J. (2005). Phenomenological research methods for counseling psychology. Journal of Counseling Psychology, 52(2), 167-177. http://dx.doi.org/10.1037/0022-0167.52.2.167

\section{Copyright Disclaimer}

Copyright for this article is retained by the author(s), with first publication rights granted to the journal.

This is an open-access article distributed under the terms and conditions of the Creative Commons Attribution license (http://creativecommons.org/licenses/by/3.0/). 